\title{
A VALID METHOD FOR DETERMINING THE WATER CONTENT OF THE BRAZIL NUT (Bertholletia excelsa)
}

\author{
VALIDAÇÃO DE UM MÉTODO PARA DETERMINAÇÃO DO TEOR DE ÁGUA DA \\ CASTANHA-DO-BRASIL (Bertholletia excelsa)
}

\author{
Luciano de Magalhães MONTEIRO' ${ }^{1}$; Roberta Martins NOGUEIRA ${ }^{2}$; Evaldo Martins PIRES ${ }^{2}$ \\ 1. Graduado em Física, Mestre em Ciências Ambientais, Universidade Federal de Mato Grosso, Sinop, MT, Brasil; 2. Professores \\ Doutores, Universidade Federal de Mato Grosso, Sinop, MT, Brasil. evaldo.pires@ gmail.com
}

\begin{abstract}
For proper handling of a product knowledge regarding its water content is essential. To provide fast, inexpensive and reliable results, the direct evaporation method of water in oil bath (EDABO) has been proven to be a viable alternative, at all stages of production of the Brazil nut. Therefore, adaptation and validation of the EDABO method for the almonds was developed using ten lots, five for each stage, maintaining the water content range between 3.73 and $29.13 \%$ w.b, which is the typical water content range for the product from the collection phase until its final marketing. The oil bath temperatures tested were $150^{\circ} \mathrm{C}$ to $200^{\circ} \mathrm{C}$, from 10 to $10^{\circ} \mathrm{C}$ for the adaptation step. The results thus obtained were compared with the water content recorded for the same batch employing the vacuum oven method as the standard. In the adaptation step the most suitable temperature range was set. Next, the method was validated to test for the precision, accuracy and linearity of the pre-set temperature range. During this step, temperature of $150^{\circ} \mathrm{C}$ were observed to ensured water content results consistent with those determined by the standard method. In the validation step the temperature of $150^{\circ} \mathrm{C}$ revealed precision, accuracy and linearity and were comparable to the standard method. Therefore, considering the technical aspects for implementation of this method, it was concluded that $150^{\circ} \mathrm{C}$ temperature was validated.
\end{abstract}

KEYWORDS: EDABO. Moisture content. Validation of method.

\section{INTRODUCTION}

The seeds of Bertholletia excelsa H.B.K., popularly termed Brazil nut, (LORENZI, 1992) occurs in the upland areas of the Amazon region (SOUZA et al., 2008; LOUREIRO et al., 1979; LOUREIRO; SILVA, 1968), in countries including Bolivia, Colombia, Guyana, Venezuela, Peru and Brazil (MORI et al., 1990). As members of the Lecythidaceae family, they represent the major plant species in the region (MARTINS; MARTINS, 2011), and are found in the states of Acre, Amapá, Amazonas, Mato Grosso, Pará, Rondônia, Roraima and Tocantins, in Brazil (LORENZI, 1992). Nut extraction forms one of the main economic activities for families inhabiting this region (JUNIOR et al., 2000 ), producing in $2014, \mathrm{R} \$ 79,565,000.00$, from 37,499 tons of the extracted product (IBGE, 2015).

Protected by a woody, triangular seed coat and encapsulated like sea urchins (LORENZI, 1992) the seeds are botanically described as a capsule "poricida" (BARROSO, 1999) or "pixídio" (JOLY, 1985). The thick woody domed shell is highly resistant, protecting the seeds from inclement weather, physical and chemical damage, and has earned the nickname "hedgehog" (SCUSSEL et al., 2014). Although the fruit of the Bertholletia genus have a hole in the pericarp it does not allow the loss of the seeds (BARROSO, 1999).
As the almond represents a good quantity and quality protein profile (SUN et al., 1987), with high selenium content (LOCATELLI et al., 2005) and a good lipid profile (LIMA et al., 2011) there is a growing demand for it in the food industry. Another factor which makes it a wise choice to grow is the utilization of its by-products. The broken or whole nuts of low commercial value find use in the production of flour, cereal bars, cookies, etc., while the skins can be used as fuel, and even the 'hedgehog' is being widely used in the manufacture of handmade artifacts (LOCATELLI et al., 2005).

Besides the chemical composition of organic products, the water naturally present (MILMAN, 2002), enables the product to interact with the surrounding biotic factors or to trigger internal chemical reactions which results in the weight loss of the product (CELESTINO, 2010).

Therefore, knowledge regarding the water content of the product is crucial in determining the likelihood of the product to deteriorate. This influences the ability to decide on the operation unit required, either before or during the industrial processing, such as drying, storage and aeration, among others (KAISJER et al., 2000).

Innumerable methods are available for determining the water content of vegetable products (SHEI; LIN, 2012; ILELEJI et al., 2010; SILVA, 2008), but it is the physical and chemical 
characteristics of each product that determines the appropriate method for each variety (Institute Adolfo Lutz, 2008). Besides the suitability of the method based on the product characteristics, factors like cost, run-time and method accuracy also assume utmost significance for them to be utilized by the industry or even the producers (SILVA, 2008).

Brazil nuts or almonds in particular, unlike the other plant products like corn, soybeans and others, lack validated water content determination methods. This is further aggravated by the chemical characteristics of the product, specifically with respect to the content and the lipid profile, with great inclination for the traditional gravimetric methods, involving the use of an oven with air circulation, for example (Instituto Adolfo Lutz, 2008). One solution for this issue is the utilization of vacuum oven at low temperatures, which is most appropriate for high lipid content products. However, besides involving high equipment cost, the time required for obtaining the result is also too long, considering the necessity for water content values virtually instantly, in the industry (MATHLOUTJI, 2001).

Therefore, alternative water content determination methods, to the ones traditionally employed at the level of the laboratory experiments, have been developed and validated for several agricultural products (SARMENTO et al, 2015; KANDALA et al., 2013; SUNDARAM et al., 2012). These methods, besides providing precise results, also need to quickly perform the analysis, be inexpensive and be performed in the field or in the industry, without involving the use of high precision equipment. One such method is the evaporation direct water in oil bath, known by the acronym EDABO (SABIONI; SILVA, 1984) from the Brown-Duvel distillation, which includes all the positive features for an alternative method. However, its operating characteristics need to be validated for each product, such as sample preparation and the oil bath temperature.

Thus, in light of the urgent need for a water content determination method, validated for the Brazil nut, and which is usable in both the previous steps or during industrial processing, this work aimed to validate the EDABO method for the Brazil nut in shell.

\section{MATERIAL AND METHODS}

Brazil nut in shell samples were obtained in a processing plant located in the municipality of Sinop, Mato Grosso, Brazil.
The experiments were conducted in two stages: the first, termed 'adaptation' was performed to determine the sample preparation method, as well as define a narrower range of the oil bath temperature to validate it; the second step, 'validation', was done to check, within the range defined in the prior step, at the most suitable temperature for implementing the method.

Five lots were employed in the adaptation stage and five others to validate the EDABO method. Each lot were collected at different stages, from the time of arrival of the freshly harvested product in the industry, until its final commercialization, which represented the greatest possible water content range for the product under real processing conditions.

Each batch represented a sample drawn from the nuts of the same processing step, obtained from five collections over a day. They were homogenized and segregated for water content determination by the reference method and the EDABO method.

The reference method to assess the water content of the batch was performed in an oven, under reduced pressure $(\mathrm{p} \leq 100 \mathrm{mmHg})$ at $70{ }^{\circ} \mathrm{C}$, called a vacuum oven. Five replicates were done for each batch in the vacuum oven until constant weight was achieved; each replicate consisted of five nuts in shell, selected randomly from each batch. After achieving constant weight, the water contents were determined by the difference between the initial sample mass and the final mass (Instituto Adolfo Lutz, 2008).

In the EDABO method, the temperatures tested were $150,160,170,180,190$ and $200{ }^{\circ} \mathrm{C}$. Inside a metal container of 1 liter volume, $50 \pm 10 \mathrm{~g}$ Brazil nuts in shell were weighed. To prevent the explosion of nuts, due to the increase in vapor pressure between the nut and the shell, the shells were first broken to maximize the area for the steam outlet. The nuts were then covered with refined soybean oil, the container was capped with a perforated cap and a thermometer inserted into the container, to record the oil bath temperature. The entire assembly was weighed and transferred for heating to the temperature of the test in question. Once the desired temperature was reached, the heat source was removed and the whole unit was allowed to naturally cool down and re-weighed. The water content of the sample was determined by recording the difference between the mass of the assembly before and after heating, to give the sample mass used.

The results obtained from the adaptive tests were used to define the temperatures to be validated 
for the EDABO method. At this stage the analysis was performed for the set temperatures, to compare the accuracy, linearity and precision of the water content results with those obtained using the reference method according to Brito et al. (2003). Besides these parameters, the repeatability and reproducibility of the method were evaluated. To accomplish the first the coefficient of variation $(\mathrm{CV})$ of the data was used, whereas for the second, a few replications were performed with a change in operator, equipment and the temperature and relative humidity conditions of the environment.

The water content data obtained from all the steps of the adaptation and validation of the EDABO method and the vacuum oven method were submitted to Lilliefors normality test. Then the analysis of variance (ANOVA) was done, followed by Tukey's test between the reference data and those obtained in the EDABO method, at different temperatures.

For the validation step, besides the statistical methods described above, a linear regression model was fitted between the vacuum oven method and the EDABO method by calculating the curve adjustment parameter $\left(\mathrm{R}^{2}\right)$. The linearity was then tested based on the adjusted model, as well as by exclusive invalid assumptions, the intercept and slope of the model, and the possibility of invalidity combined as follows:
1) $\mathrm{H} 0: \beta 0=0 ; \mathrm{Ha}: \beta 0 \neq 0$;
2) $\mathrm{H} 0: \beta 1=0$; Ha: $\beta 1 \neq 0$;
3) H0: $\beta 1=0$ and $\beta 0=0$; Ha: $\beta 0 \neq 0$ and $\beta 1$

$\neq 0$;

In the case of accepting the first hypothesis of nullity, it was concluded that the model intercept is significant. Regarding the second null hypothesis, in case of its non-rejection, it appears that the slope of the model is not null. In the case of non-rejection of the joint null hypothesis, the third to be tested indicates the equivalence seen between the values obtained by using different methods.

All the statistical procedures were performed using Action Stat software and 0.05 was adopted as the significance level for type I error.

\section{RESULTS}

Table 1 shows the results of the tests for the average water content of the five batches done, implementing the reference method and the EDABO method at different temperatures. In the adaptation phase, the mean values of the water content of the lots recorded from the reference method, ranged from 6.35 and $18.92 \%$ w.b. with standard deviation (SD) ranging from 0.43 to 1.38 (Table 1). In the case of those subjected to the EDABO method, the same batches showed the average water content ranging from $6.96 \%$ to $18.76 \%$ w.b., with SD of 0.30 to 0.80 at $150{ }^{\circ} \mathrm{C}$ temperature; 7.81 to $20.17 \%$ w.b. and SD of 0.37 to 0.80 at $160{ }^{\circ} \mathrm{C}$ temperature; between 8.15 . and $22.25 \%$ w.b. and SD of 0.43 to 0.57 at $170^{\circ} \mathrm{C}$ temperature; between $9.00 \%$ and $21.36 \%$ w.b. and SD of 0.33 to 1.18 at $180{ }^{\circ} \mathrm{C}$ temperature; ranging from 9.02 to $22.31 \%$ w.b. and SD of 0.06 to 0.98 for $190{ }^{\circ} \mathrm{C}$ temperature; and 9.83to $23.20 \%$ w.b. and SD of 0.31 to 0.78 for 200 ${ }^{\circ} \mathrm{C}$ temperature (Table 1), performing to check the tendency of the EDABO method to introduce overestimated values of the water content of the samples as a function of the increasing of temperature in the oil bath.

Table 1. Water contents obtained in the adaptation phase of the EDABO method

Water content (\%w.b.) Mean \pm S.D.

\begin{tabular}{|c|c|c|c|c|c|}
\hline & Lot 1 & Lot 2 & Lot 3 & Lot 4 & Lot 5 \\
\hline OVEN & $6.35 \pm 0.43 \mathrm{a}$ & $7.91 \pm 0.57 \mathrm{ab}$ & $10.84 \pm 1.38 \mathrm{ab}$ & $14.43 \pm 0.87 \mathrm{ab}$ & $18.92 \pm 0.85 \mathrm{a}$ \\
\hline ED $150{ }^{\circ} \mathrm{C}$ & $6.96 \pm 0.30 \mathrm{a}$ & $7.69 \pm 0.52 \mathrm{a}$ & $10.34 \pm 0.80 \mathrm{a}$ & $13.15 \pm 0.72 \mathrm{a}$ & $18.76 \pm 0.78 \mathrm{a}$ \\
\hline ED $160^{\circ} \mathrm{C}$ & $7.81 \pm 0.37 b$ & $8.15 \pm 0.53 a b$ & $10.86 \pm 0.80 \mathrm{ab}$ & $14.71 \pm 0.59 \quad b$ & $20.17 \pm 0.65 a b$ \\
\hline ED $170^{\circ} \mathrm{C}$ & $8.15 \pm 0.45 \mathrm{~b}$ & $8.92 \pm 0.53$ bc & $11.44 \pm 0.54$ bcd & $15.09 \pm 0.43 \mathrm{~b}$ & $22.25 \pm 0.57$ \\
\hline ED $180^{\circ} \mathrm{C}$ & $9.00 \pm 0.33 \mathrm{c}$ & $9.68 \pm 0.66 \mathrm{~cd}$ & $12.45 \pm 0.54 \mathrm{~cd}$ & $15.45 \pm 0.71 \mathrm{bc}$ & $21.36 \pm 1.18$ bcd \\
\hline ED $190^{\circ} \mathrm{C}$ & $9.02 \pm 0.06 \mathrm{c}$ & $10.30 \pm 0.44$ & $12.85 \pm 0.98$ & $16.52 \pm 0.23 \mathrm{~cd}$ & $22.31 \pm 0.55$ \\
\hline ED $200^{\circ} \mathrm{C}$ & $9.83 \pm 0.47 \quad d$ & $9.69 \pm 0.31 \mathrm{~cd}$ & $13.24 \pm 0.53$ & $16.95 \pm 0.46$ & $23.20 \pm 0.78$ \\
\hline
\end{tabular}

For Lot 1, the Tukey test reveals that the EDABO method at $150{ }^{\circ} \mathrm{C}$ temperature showed values similar to that of the reference method. For Lot 2 the EDABO method at 150,160 and $170{ }^{\circ} \mathrm{C}$ 
temperatures did not differ from those with the oven method. Similar behavior was seen for between Lots 2 and 3. With respect to Lot 4, besides the temperatures of $150,160,170{ }^{\circ} \mathrm{C}$, as for Lots 2 and 3 , the EDABO method at $180{ }^{\circ} \mathrm{C}$ also showed a water content mean value not different from that of the reference method. The 5 th batch, at temperatures of only $150{ }^{\circ} \mathrm{C}$ and $160{ }^{\circ} \mathrm{C}$ yielded results similar to those obtained in the oven, by Tukey test at $5 \%$ significance.

When the average of the test results for the five batches during the adaptation phase was considered, it was observed that only at $150{ }^{\circ} \mathrm{C}$ of boiling temperature, the water content results showed values not different from those of the reference method (Table 1). Thus, during the validation phase, the EDABO method at $150{ }^{\circ} \mathrm{C}$ temperature was tested for accuracy, precision, linearity, repeatability and reproducibility.

Thus, the validation step (Table 2), showed mean reference water contents ranging from 3.73to $29.13 \%$ w.b.. The same batch, when subjected to the EDABO method at $150^{\circ} \mathrm{C}$ temperature showed results ranging from 3.24 and $27.85 \%$ w.b., values that were not different from the reference method by the Tukey test at $5 \%$ significance level.

The coefficients of variation (CV) calculated from the water content data obtained in the oven ranged between 0.72 and $1.69 \%$, whereas for the EDABO method at $150{ }^{\circ} \mathrm{C}$, they ranged from 3.56 to $5.26 \%$. For reference values, the standard deviation ranged from 0.04 to 0.21 , whereas for the EDABO method at $150{ }^{\circ} \mathrm{C}$, the variation was 0.17 to 1.47 , as shown in Table 2.

Table 2. Water contents obtained in the validation phase of the EDABO method

\begin{tabular}{lccccccccccc}
\hline & \multicolumn{8}{c}{ Water content (\%w.b.) Mean \pm S.D. } \\
\cline { 2 - 12 } & Lot 6 & $(\mathbf{C V})$ & Lot 7 & $(\mathbf{C V})$ & Lot 8 & $(\mathbf{C V})$ & Lot 9 & $(\mathbf{C V})$ & Lot 10 & $(\mathbf{C V})$ \\
\hline OVEN & $3.73 \pm 0.04$ & 1.05 & $6.63 \pm 0.11$ & 1.69 & $13.38 \pm 0.19$ & 1.38 & $19.45 \pm 0.19$ & 0.95 & $29.13 \pm 0.21$ & 0.72 \\
\hline $\begin{array}{l}\text { ED } \\
150^{\circ} \mathrm{C}\end{array}$ & $3.24 \pm 0.17$ & 5.20 & $5.68 \pm 0.20$ & 3.56 & $13.21 \pm 0.49$ & 3.74 & $18.73 \pm 0.74$ & 3.97 & $27.85 \pm 1.47$ & 5.26 \\
\hline
\end{tabular}

The linear model set between the water content data obtained by the reference method with those obtained by the EDABO method at $150{ }^{\circ} \mathrm{C}$, showed the coefficient of determination $\left(\mathrm{R}^{2}\right)$ of 0.9936. The estimated intercept of the curve was $\beta 0$ $=-0.0042$ and value-P1 $\mathrm{P}=0.14$, with tilt $\beta 1=$ 0.9784 and $\mathrm{p}$-value was not significant, and the same was observed for the possibility of joint nullity, as shown in Table 3. In Figure 1, the linear model fit between the values of the reference method and EDABO method at $150{ }^{\circ} \mathrm{C}$ is shown, including all the points obtained for each batch, which are extremely close to the central trend line.

Table 3. Parameters of the regression model fitted between the water content values for oven and EDABO methods

\begin{tabular}{|c|c|c|c|c|c|c|}
\hline \multicolumn{7}{|c|}{ Parameters } \\
\hline \multirow{2}{*}{ Item } & \multicolumn{2}{|c|}{ Intercept } & \multicolumn{2}{|c|}{ Tilt } & \multirow{2}{*}{$\mathbf{P}^{3}$} & \multirow{2}{*}{$\mathbf{R}^{2}$} \\
\hline & $\beta_{0}$ & $\mathbf{P}^{1}$ & $\beta_{1}$ & $\mathbf{P}^{2}$ & & \\
\hline STD - ED 150 & -0.0042 & 0.14 & 0.9784 & NS & NS & 0.9936 \\
\hline
\end{tabular}

$\mathrm{STD}=$ Standard method (vacuum oven); ED $150=\mathrm{EDABO}$ subjected to $150{ }^{\circ} \mathrm{C} ; \mathrm{NS}=$ Not significant

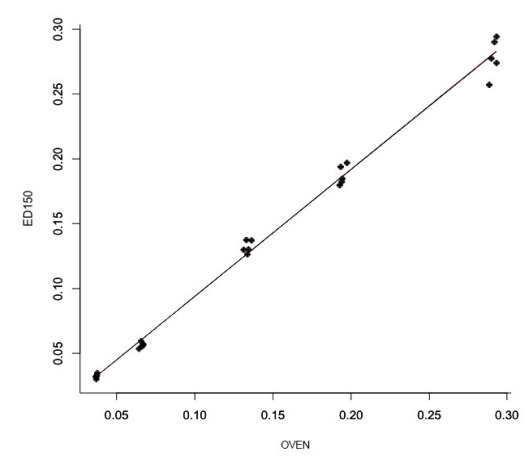

Figure 1. Linear regression model between the water content obtained in EDABO at $150{ }^{\circ} \mathrm{C}$ in a vacuum oven. 


\section{DISCUSSION}

The low standard deviation of the values obtained from both the reference and EDABO methods demonstrates uniform water conten in both batches, even though they originated from a composite sample. This is explained by the fact that each batch was drawn from one step of the production process, in a single day, reducing the chances of deriving individual samples from very different sources.

The statistical procedures performed with the data obtained from the adaptation phase, revealed that only at the oil bath temperature of 150 ${ }^{\circ} \mathrm{C}$ in the EDABO method results were produced that did not differ from that of the reference method. This result corroborates the behavior for the agricultural products having a chemical composition similar to the Brazil nut, mainly in terms of the high lipid and protein content, as in the case of soybeans, whose temperature validated by the EDABO method is $135{ }^{\circ} \mathrm{C}$, or beans exposed to $175{ }^{\circ} \mathrm{C}$ temperatures, according to Silva (2008).

Regarding the water content values recorded using the EDABO method, at different temperatures, it was noted that the increase in the temperature of the product displayed in the oil bath resulted in an overestimated water content reading when compared with the reference method. This can be explained by the fact that, when the product temperature increased, volatiles might have been formed by lipid oxidation (CHOE; MIN, 2007; WĄSOWICZ et al., 2004) which would evaporate together with the water, especially for those samples with higher water contents. This is explained by the action of the lipoxidant enzymes that act on the lipid substrate in the more moist products, because, under such conditions, the enzyme pro-oxidant reactions are favored. This factor linked to high temperature enhances the lipid oxidation and the release of the volatile substances, resulting in an overestimation of the water content due to the increased exposure of the sample to temperature and water content (PRADO-FILHO, 1994).

The lipid oxidation in the more moisturerich Brazil nuts was verified by Prado-Filho (1994). $\mathrm{He}$ subjected them to storage for six days at different water activity values (Aw), where, for greater Aw values, with each passing day, the nuts revealed higher peroxide levels, which could lead to the production of secondary volatile compounds. Several authors refer to lipid oxidation accompanying an increase in the feed temperature, as in the case Aquino et al. (2009) who noted oxidation during drying the "pequi" fruit (Caryocar brasiliense Camb.) at high temperature. Adeeko and Jibola (1990) studying the drying of peanuts (Arachis hypogaea L.) noted similar behavior.

Overestimation of the water content can result in several operating losses during the Brazil nut processing, as in the case of overdrying, with the consequent oxidation of the product, store or product packaging with insufficient moisture.

The water content range for the validated EDABO method at $150^{\circ} \mathrm{C}$ temperature was higher than that tested in the adaptation phase, containing water content that typically ranged from the product collection phase $(29.13 \%$ w.b.) done in the forest (NOGUEIRA et al., 2014) until the product commercialization $(3.73 \%$ w.b.) phase (ÁLVARES et al., 2012).

Utilizing the $\mathrm{CV}$, it is possible to infer that the variations in the results was less than $6 \%$ for the EDABO method at $150{ }^{\circ} \mathrm{C}$, for all the lots tested, which along with the standard deviation below 1.5 (Table 2) attests to the accuracy of the method. Precision behavior was also important and needed to be checked by the vacuum oven method, which yielded CV value below $2 \%$, attesting that it can produce such an important feature for reference. Another inference that can be drawn from the low $\mathrm{CV}$ values recorded was the reproducibility and repeatability of the method demonstrated by the fact that both the reference and EDABO methods were performed by different operators and equipment and even under different environmental conditions in some replicates, demonstrating the robustness of the method.

Finally, based on the linear model adjusted between the water content values obtained by the reference method and those recorded from the EDABO method at $150{ }^{\circ} \mathrm{C}$, a strong correlation was observed between them, as attested by the value of the coefficient of determination $\left(\mathrm{R}^{2}\right)$, being close to 1. Linearity was confirmed by testing the three hypotheses, done for the estimated coefficients of linear function. Given a perfect linear function between the two methods, we required a model with zero intercept and slope equal to 1 . Thus, as the adjusted intercept value of -0.0042 was very close to the expected value, and confirmed by the $\mathrm{p}$-value $\left(\mathrm{P}^{1}\right)$ of 0.14 , it disallows the rejection of the first hypothesis tested nullity. Already the adjusted intercept of 0.9784 was also very close to the expected value, as well as confirmed by the p-value $\left(\mathrm{P}^{2}\right)$ not being significant, it allows rejection of the hypothesis that the intercept was equal to zero (case 2 ). Finally, the linearity was confirmed by the joint hypothesis (hypothesis 3 ) in which the p-value $\left(\mathrm{P}^{3}\right)$ too was not significant. 


\section{CONCLUSIONS}

The EDABO method was validated for a wide range of water content for Brazil nut. It can be implemented in products between 3.73 to $29.13 \%$ w.b., right from the product collection in the forest until its final marketing stage.

To safely execute the EDABO method for determining the water content of the Brazil nut, bark
MONTEIRO, L. M. et al.

samples should be used for about $50 \mathrm{~g}$ of the product with their shells broken to prevent the shells exploding in the oil bath.

The temperature of $150{ }^{\circ} \mathrm{C}$ has been validated as the optimum, which produced results similar to those derived from the reference method for the Brazil nut, proven by testing accuracy, precision and linearity.

RESUMO: Para o manuseio adequado de um produto, conhecimento do seu teor de água é essencial. Por fornecer resultados rápidos, baratos e confiáveis, o método de evaporação direta da água no banho de óleo (EDABO) é comprovadamente uma alternativa viável para se conhecer o teor de água do produto, em todas as fases de produção da castanha-do-brasil. Para isso o método EDABO para as amêndoas foi desenvolvido utilizando-se dez lotes, cinco para a fase de adaptação e os outros cinco para a fase de validação, mantendo a faixa de teor de água entre 3,73 e $29,13 \%$ b.u.. Esta é a faixa de teor de água típica para o produto a partir da fase de extração até sua comercialização final. As temperaturas do banho de óleo testadas foram 150 a $200{ }^{\circ} \mathrm{C}$, a cada $10{ }^{\circ} \mathrm{C}$ durante a adaptação. Os resultados obtidos foram comparados com o teor de água registrado para o mesmo lote empregando o método da estufa a vácuo como o referência. Na etapa de adaptação foi definida a faixa de temperatura mais adequada. Em seguida, o método foi validado para testar a precisão, exatidão e linearidade da faixa de temperatura pré-definida. Durante a adaptação, somente a temperatura de $150{ }^{\circ} \mathrm{C}$ apresentou resultados de teor de água consistentes com aqueles determinados pelo método de referência. Na etapa de validação, a temperatura de $150{ }^{\circ} \mathrm{C}$ revelou precisão, exatidão e linearidade e foram equivalentes àqueles determinados pelo método da estufa a vácuo. Portanto, considerando os aspectos técnicos para a implementação deste método, concluiu-se que $150{ }^{\circ} \mathrm{C}$ de temperatura foi validado.

PALAVRAS-CHAVES: EDABO. Umidade. Validação de método.

\section{REFERENCES}

ADEEKO, K. A.; JIBOLA, O. O. A. Processing factors affecting yield and quality of mechanically expressed groundnut oil. Journal of Agricultural Engineering Research, Cranfield, v. 45, n. 1, p. 31-43, 1990. http://dx.doi.org/10.1016/S0021-8634(05)80136-2

ÁlVARES, V. S.; CASTRO, I. M.; COSTA, D. A.; LIMA, A. C.; MADRUGA, A. L. S. Qualidade da castanha-do-brasil do comércio de Rio Branco, Acre. Acta Amazônica, Manaus, v. 42, n. 2, p. 269-274, 2012. http://dx.doi.org/10.1590/S0044-59672012000200013

AQUINO, L. P.; FERRUA, F. Q.; BORGES, S. V.; ANTONIASSI, R.; CORREA, J. L. G.; CIRILO, M. A. Influência da secagem do pequi (Caryocar brasiliense Camb.) na qualidade de oleo extraído. Ciência e Tecnologia de Alimentos, Campinas, v. 29, n. 2, p. 354-357, 2009. http://dx.doi.org/10.1590/S010120612009000200018

BARROSO, G. M.; MORIN, M. P.; PEIXOTO, A. L.; ICHASO, L. F. Frutos e sementes. Morfologia aplicada à sistemática de Dicotiledôneas. 1. ed. Viçosa: Editora UFV, 1999. 443 p.

BRITO, N. M.; JÚNIOR, O. P. A.; POLESE, L.; RIBEIRO, M. L. Validação de métodos analíticos: estratégia e discussão. Pesticidas: Revista de Ecotoxicologia e Meio Ambiente, Curitiba, v. 13, n. 1, p. 129-146, 2003.

CELESTINO, S. M. C. Princípios de Secagem de Alimentos. Planaltina: Embrapa Cerrados. 2010, 51 p.

CHOE, E.; MIN, D. B. Chemistry of deep-fat frying oils. Journal of Food Science, Bethesda, v. 72, n. 5, p. R77-R86, 2007. http://dx.doi.org/10.1111/j.1750-3841.2007.00352.x 
ILELEJI, K. E.; GARCIA, A. A.; KINGSLY, A. R. P.; CLEMENTSON, C. L. Comparison of standard moisture loss-on-drying methods for the determination of moisture content of corn distillers dried grains with solubles. Journal of AOAC International, Rockville, v. 93, n. 3, p. 825-832, 2010.

INSTITUTO ADOLFO LUTZ. Métodos físico-químicos para análise de alimentos. 4. ed. São Paulo: Instituto Adolfo Lutz. 2008. 1020 p.

INSTITUTO BRASILEIRO DE GEOGRAFIA E ESTATÍSTICA - IBGE. 2015. Disponível em: $<\mathrm{http}: / /$ www.sidra.ibge.gov.br/bda/tabela/protabl.asp?c=290\&z=p\&o=30\&i=P> Acesso em: 03 janeiro de 2016.

JOLY, A. B. Botânica: Introdução à taxonomia vegetal. 7. ed. São Paulo: Companhia Editora Nacional, 1985. $777 \mathrm{p}$.

JÚNIOR, J. D. B. N.; CARVALHO, R. A.; HUHN, S.; NAZARÉ, R. F. R. Castanha-do-brasil como fonte de renda das áreas Quilombolas de Oriximiná, PA. Belém: Embrapa Amazônia Oriental. Documentos 50, 2000. 57 p.

KAIJSER, A.; DUTTA, P.; SAVAGE, G. Oxidative stability and lipid composition of macadamia nuts grown in New Zealand. Food Chemistry, Amsterdam, v. 71, n. 1, p. 67-70, 2000. http://dx.doi.org/10.1016/S03088146(00)00132-1

KANDALA, C. V.; AVULA, R.; SETTALURI, V.; REDDY, R. S.; PUPPALA, N. Sensing the moisture content of dry cherries-A rapid and nondestructive method. Food and Nutrition Sciences, New York, v. 4, n, 9B, p. 38-42, 2013. http://dx.doi.org/10.4236/fns.2013.49A2006

LIMA, D. M.; PADOVANI, R. M.; RODRIGUEZ-AMAYA, D. B.; FARFÁN, J. A.; NONATO, C. C.T.; LIMA, M. T. Tabela brasileira de composição de alimentos. 4. ed. revisada e ampliada. Campinas: NEPA UNICAMP, 2011. $161 \mathrm{p}$.

LOCATELli, M.; VIEIRA, A. H.; GAMA, M. M. B.; FERREIRA, M. G. R.; MARTINS, E. P.; FILHO, E. P. S.; SOUZA, V. F. \& MACEDO, R. S. Cultivo da castanha-do-brasil em Rondônia. Embrapa Rondônia Sistemas de produção, 7. Versão electronica. 2005. Disponível em: < https://sistemasdeproducao.cnptia.embrapa.br/FontesHTML/Castanha/CultivodaCastanhadoBrasilRO/index.ht $\mathrm{m}>$. Acesso em: 12 de janeiro de 2016.

LORENZI, H. Árvores brasileiras: manual de identificação e cultivo de plantas arbóreas do Brasil. 4. ed. v. 1. Nova Odessa, São Paulo: Instituto Plantarum, 1992, 368 p.

LOUREIRO, A. A.; SILVA, M. F. Catálogo de madeiras da Amazônia. v. 2. Belém: SUDAM, 1968. 411 p.

LOUREIRO, A. A.; SILVA, M. F.; ALENCAR, J. C. Essências madeireiras da Amazônia. 2. ed. Manaus: INPA/SUFRAMA, 1979. $245 \mathrm{p}$.

MARTINS, L. M. O.; MARTINS, W. M. O. Parâmetros de qualidade de amêndoas de castanha-do-brasil comercializadas em Rio Branco - Acre. Revista Brasileira de Tecnologia Agroindustrial, Curitiba, v. 5, n. 2, p. 542-549, 2011. http://dx.doi.org/10.3895/s1981-36862011000200006

MATHLOUTJI, M. Water content, water activity, water structure and the stability of foodstuffs. Food Control, v. 12, n. 7, p. 409-417, 2001. http://dx.doi.org/10.1016/S0956-7135(01)00032-9

MILMAN, M. J. Equipamentos para pré-processamento de grãos. Pelotas: 1. ed. Editora Universitária/UFPel, 2002. 206 p. 
MORI, S. A.; PRANCE, G. T.; ZEEUW, C. H. Lecythidaceae, Part 2. The Zygomorphic-Flowered New World Genera (Couroupita, Corythophora, Bertholletia, Couratari, Eschweilera, \& Lecythis), With a Study of Secondary Xylem of Neotropical Lecythidaceae. New York: New York Botanical Garden, 1990. 373 p.

NOGUEIRA, R. M.; ALVARES, V. S.; RUFFATO, S.; LOPES, R. P.; SILVA, J. S. Physical properties of Brazil nuts. Engenharia Agrícola, Jaboticabal, v. 34, n. 5, p. 963-971, 2014.

PRADO-FILHO, L. G. Umidade relativa de equilíbrio e oxidação de lipídeos em farinhas de castanha do Pará, de macadâmia e de soja. Science Agrícola, Piracicaba, v. 51, n. 2, p. 357-362, 1994.

http://dx.doi.org/10.1590/S0103-90161994000200023

SABIONI, P. M.; SILVA, S. J. Construção do determinador de umidade DUPEA. In: Seminário, 1984, Viçosa. Informe Técnico. Viçosa: Imprensa Universitária da UFV, 1984. v. 1. p. 1-8.

SARMENTO, H. G. S. S.; DAVID, A. M. S. S.; BARBOSA, M. G.; NOBRE, D. A. C. N.; AMARO, T. R. Determinação do teor de água em sementes de milho, feijão e pinhão-manso por métodos alternativos. Energia na Agricultura, Botucatu, v. 30, n. 3, p. 249-256, 2015.

SCUSSEL, M. V.; MANFIO, D.; SAVI, G. D.; MOECKE, E. H. Stereoscopy and scaning electron microscopy of Brazil nut (Bertholletia excelsa H.B.K.) shell, brown skin, and edible part: part one - healthy nut. Journal of Food Science, Bethesda, v. 79, n. 7, p. H1443-H1453, 2014. http://dx.doi.org/10.1111/1750-3841.12502

SHEI, H. J.; LIN, C. S. An optical automatic measurement method for the moisture content of rough rice using image processing techniques. Computers and Electronics in Agriculture, Amsterdam, v. 85, n. 6, p. 134-139, 2012. http://dx.doi.org/10.1016/j.compag.2012.04.012

SILVA, J. S. Secagem e armazenamento de produtos agrícolas. Viçosa. 2. ed. Aprenda Fácil, 2008. 560 p. SOUZA, C. R.; AZEVVEDO, C. P.; ROSSI, L. M. B.; LIMA, R. M. B. Castanha-do-brasil (Bertholletia excelsa Humb. \& Bonpl). Manaus: Embrapa Amazônia Ocidental, 2008. 22 p.

SUN, S. S. M.; LEUNG, F. W.; TOMIC, J. C. Brazil nut (Bertholletia excelsa H.B.K.) proteins: fractionation, composition, and identification of a sulfur-rich protein. Journal of Agricultural and Food Chemistry, Washington, DC, v. 35, n. 2, p. 232-235, 1987. http://dx.doi.org/10.1021/jf00074a016

SUNDARAM, J.; KANDALA, C. V.; GOVINDARAJAN, K. N.; SUBBIAH, J. Sensing of moisture content of in-shell peanuts by NIR reflectance spectroscopy. Journal of Sensor Technology, California, v. 2, n. 1, p. 1-7, 2012. http://dx.doi.org/10.4236/jst.2012.21001

WĄSOWICZ, E.; GRAMZA, A.; HÉS, M.; JELÉN, H. H.; KORCZAK, J.; MALECKA, M.; MILDNERSZKUDLARZ, S.; RUDZINSKA, M.; SAMOTYJA, U.; ZAWIRSKE-WOJTASIAK, R. Oxidation of lipids in food. Polish Journal of Food and Nutrition Sciences, Olsztyn, v. 13/54, n. 1s, p. 87-100, 2004. 